\title{
The Impact of Radio Frequency Identification (RFID) Investment Announcements on the Market Value of the Firm
}

\section{Bong-Keun Jeong ${ }^{1}$ and Ying $\mathrm{Lu}^{2}$}

\author{
${ }^{1}$ University of North Carolina at Charlotte, BISOM Department, bjeong@uncc.edu \\ ${ }^{2}$ University of North Carolina at Charlotte, BISOM Department, ylu5@uncc.edu
}

Received 2 August 2007; received in revised form 7 January 2008; accepted 22 January 2008

\begin{abstract}
This paper examines the impact of RFID investment announcements on the market value of the firms and explores industry effects of the positive abnormal returns to firms making the announcements. Drawing upon the efficient market theory, market signaling hypothesis, and prior empirical studies, we employ event study methodology to analyze RFID investment announcements over a six-year period from 2001 to 2006 . In this paper, we present preliminary results that demonstrate an overall positive abnormal return to RFID investment announcements over the three-day event window. In addition, industry differences in market returns to RFID investment announcements are observed with a greater return realized in the manufacturing sector and specifically in the information technology industry segment and for technology vendors' investment initiatives. These preliminary findings provide useful implications for a better understanding of the benefits of RFID adoption and for making decisions in RFID investment and adoption to create value for the firms.
\end{abstract}

Key words: RFID Investment, Event Study, Market Value, Industry Effects, Announcement 


\section{Introduction}

Effective supply chain management (SCM) has been a focus of many organizations. In today's hypercompetitive business environment, companies often make significant investments in developing integrated supply chain strategies to ensure that all the functions and activities involved in the value chain are working together harmoniously and to attain competitive advantages [18]. As supply chain networks become more mature and complex, the needs for more efficient supply chain technology solutions have also increased dramatically [20]. Radio Frequency Identification (RFID) has recently received significant attention as a viable option in an organization's supply chain management (SCM) strategy. RFID is an automatic identification technology that uses radio waves to uniquely track individual objects including items, animals, or even humans [26]. RFID is expected to provide greater collaboration capabilities across value chains given its ability for real-time identification and tracking over long distances without line-of-sight requirements. Other major benefits of RFID in SCM include labor reduction throughout the supply-chain network and better inventory management that can yield significant cost savings and improved data collection with greater accuracy [2], [17].

Despite the fact that the promises of RFID technology seems to be compelling and some even believe RFID will fundamentally transform the way of doing business, the adoption rate is rather moving at modest pace [5]. For instance, the warehouse study reported that only $15 \%$ of warehousing firms had adopted RFID while $41 \%$ responded considering the adoption and $44 \%$ not considered the adoption at all [14]. Surprisingly, a primary reason for the adoption of RFID in those firms was because that Wal-Mart had made the adoption of RFID mandatory for its top suppliers to start tagging their merchandises. For many suppliers, they have to comply because Wal-Mart is the largest customer for many of them, although the current tag prices never seem to be cost-effective. Furthermore, many firms who are considering the adoption of RFID are yet positioned where they take "wait and see" approach. Since proposed benefits of RFID is still uncertain while it requires significant up-front investment, many companies rather put off their investment decision and hope to learn more from the early adopters [22].

In order to address the discrepancy between expected and realized benefits of RFID investment, IS researchers have studied issues such as potential benefits and risks [17], relationships in a supply chain [7], [26], and key success factors of adopting RFID [24]. Despite an abundance of theoretical perspectives of RFID investment, there is still a lack of study that empirically assesses the impact of RFID investment by early adopters. Therefore, the purpose of this paper is to examine the impacts of RFID investment announcements on the market value of the firm and explore industry effects of abnormal returns to firms making the announcements. In particular, employing event study methodology, we empirically investigate whether investors perceive and evaluate positively the announcements of RFID investment when the technology is still at the early stage of mass commercialization. As rooted in the efficient market theory, we expect that if the market believes that RFID investment announcements have a positive effect, then the value should be reflected in the stock price of the firm's common stock.

In this paper, we present preliminary results of our study that analyzes RFID investment announcements over a sixyear time period from 2001 to 2006 during which RFID was undergoing considerable technology change and advancement. The objective of this paper is to explore the overall market returns to RFID investment announcements and the possible industry differences in market price reactions to firms' RFID investment announcements. The findings of this paper contribute to the emerging body of RFID literature by providing initial empirical evidence of benefits of RFID investment by early adopters from the value perspective of shareholder wealth. RFID is an emerging area where it is difficult to capture full spectrum of impacts since most tangible as well as intangible benefits have not yet been discovered. As such, the study of the impacts of RFID investment announcements on market value of the firm can provide useful insights to better understand the practical implications of RFID adoption which can be helpful in making future RFID-related investment decisions and in promoting widespread diffusion of RFID to fully realize the potential value of the technology in the long term.

The structure of this paper is as follows: next section reviews relevant literature to develop the research hypotheses. The research method including data collection and data analysis approaches is discussed in the following section. This is followed by the study's results, discussion, and a brief set of conclusions.

\section{Literature Review and Hypotheses}

We review relevant literature on the impacts of RFID investment in terms of two research streams. First, we examine a literature for RFID adoption, and then discuss the broader literature on various types of information technology (IT) investment and their impacts on the market value of firms.

\subsection{RFID Adoption}

Most early research on RFID has mainly focused on describing the prospect of this technology. Since most studies are exploratory in nature, issues often addressed include technology features and application areas, benefits and risks, and the future state of RFID technology [1], [10], [17], [19]. A general assertion is that, as a new way of 
identifying and tracking items as well as exchanging information, RFID has a great potential to transform current supply chain management practices. In addition to descriptive analyses on RFID adoption, a number of prior studies focus on revealing research issues and setting an agenda for future research on RFID [7], [14]. For instance, a research agenda is proposed to address a series of questions related to how RFID technology: 1) is developed, adopted, and implemented by organizations; 2) is used, supported, and evolved within organizations and alliances; and 3 ) impacts individuals, business processes, organizations, and markets [7].

Building upon early research on RFID technology, some researchers attempt to explore strategic drivers and antecedent conditions for making decisions on RFID adoption, typically using surveys and interviews to identify key success factors related to the adoption decision. Multiple theoretical perspectives have been adopted and applied in the RFID context to explain determinants of technology adoption choice. For instance, to identify significant factors in RFID adoption, Sharma et al. proposed an integrated model which incorporates strategic choice models (diffusion of innovation theory and organizational innovativeness) where adoption is voluntary and the institutional perspective where adoption is more a result of conforming to pressure [24]. Based on a survey, the authors found 11 significant factors in the adoption of RFID such as perceived benefit, top management support, perceived standard convergence, and coercive pressures.

Table 1: Major prior studies on RFID adoption

\begin{tabular}{|c|c|c|c|}
\hline Reference & Methodology & Research Agenda & Key Findings \\
\hline [1] & $\begin{array}{l}\text { Content Analysis } \\
\text { based on } \\
\text { published report }\end{array}$ & $\begin{array}{l}\text { To introduce RFID technology with } \\
\text { several case examples and provide } \\
\text { guidelines }\end{array}$ & $\begin{array}{l}\text { Managerial guidelines for RFID } \\
\text { deployment: Make the ROI case for } \\
\text { RFID, Choose the right RFID technology, } \\
\text { Anticipate RFID problems, Manage IT } \\
\text { infrastructure, Leverage pilot project } \\
\text { learning experiences }\end{array}$ \\
\hline [7] & Not Applicable & $\begin{array}{l}\text { To propose a broad research } \\
\text { opportunities related to RFID }\end{array}$ & $\begin{array}{l}\text { Key research areas: development, } \\
\text { adoption, implementation, support, } \\
\text { evolution, impact }\end{array}$ \\
\hline$[14]$ & Not Applicable & $\begin{array}{l}\text { To propose a research agenda } \\
\text { related to RFID adoption }\end{array}$ & $\begin{array}{l}\text { Key research areas: antecedents to } \\
\text { RFID adoption, differences across } \\
\text { different types of adopters }\end{array}$ \\
\hline [17] & $\begin{array}{l}\text { Descriptive } \\
\text { Analysis }\end{array}$ & $\begin{array}{l}\text { To address the pros and cons of } \\
\text { using RFID in supply chain } \\
\text { management }\end{array}$ & $\begin{array}{l}\text { Pros: automatic non-line-of-sight } \\
\text { scanning, labor reduction, improve } \\
\text { inventory management, Cons: reliability, } \\
\text { lack of standard, privacy }\end{array}$ \\
\hline [21] & $\begin{array}{l}\text { Descriptive } \\
\text { Analysis based } \\
\text { on theories }\end{array}$ & $\begin{array}{l}\text { To provide a theoretical framework } \\
\text { and future research area for } \\
\text { applying RFID technology in } \\
\text { grocery supply chains }\end{array}$ & $\begin{array}{l}\text { Key research area: inventory } \\
\text { management, daily operation, } \\
\text { implementation }\end{array}$ \\
\hline [24] & Survey & $\begin{array}{l}\text { Factors that influence on the } \\
\text { adoption and diffusion of RFID }\end{array}$ & $\begin{array}{l}\text { Significant factors: perceived benefits } \\
\text { and costs, top management support, } \\
\text { financial readiness, IS infrastructure and } \\
\text { capabilities, perceived standard } \\
\text { convergence, perceived customer and } \\
\text { stakeholder privacy, coercive, mimetic, } \\
\text { and normative pressures }\end{array}$ \\
\hline [26] & $\begin{array}{l}\text { Descriptive } \\
\text { Analysis based } \\
\text { on theories }\end{array}$ & $\begin{array}{l}\text { Trust development in multi- } \\
\text { organizational alliances } \\
\text { implementing RFID system }\end{array}$ & $\begin{array}{l}\text { Different social categories (minority vs. } \\
\text { majority) within an alliance play an } \\
\text { important role in shaping group } \\
\text { members' perceptions and beliefs about } \\
\text { RFID }\end{array}$ \\
\hline
\end{tabular}

Another research stream focuses on analyzing complex relationships among suppliers, manufactures, distributors, and customers in RFID adoption. Since RFID technology is primarily used in an inter-organizational context such as supply chain management, a collective action is critical for the success of technology adoption. However, such a collective action is often complicated by the divergent attitudes and perceptions that different companies have about the technology which, in turn, makes it difficult to reach consensus. For instance, a recent study provided a conceptual model to examine the role of trust in the adoption of RFID system and theorized about the trust development in multi-organization contractual alliances [26]. In their paper, the authors proposed that different social categories within an alliance, especially categories formed by the differential use of RFID, play an important role in shaping group members' perceptions and belief about RFID systems as well as about each participant in the alliance. 
Table 1 presents a summary of major prior studies on RFID adoption. As can be seen, a number of RFID research has been conducted to introduce the emerging technology, to identify key success factors, and to explore the interorganizational context of adoption decisions. Yet, prior studies heavily relied on descriptive analyses which, in some sense, limit our understanding due to the lack of empirical evidence. Furthermore, despite an abundance of theoretical perspectives on RFID adoption, there is little research that empirically assesses the impact of RFID investment. Thus, our study extends prior research with an empirical examination of the impact of RFID investment announcements on the market value of the firms.

\subsection{IT Investments and Market Value of the Firm}

Firms continue to make significant investments in information technology [3]. Investments in IT have become a necessity for organizations, not only to survive in fierce competition, but more importantly to achieve sustainable competitive advantages. Accordingly, many companies consider IT as an essential investment area in order to achieve strategic goals as well as to improve operational efficiencies.

While IT has been a significant capital expenditures for many organizations, determining whether investment in IT indeed contributes to firm performance remains a challenge to researchers [9], [16]. IS researchers have recently adopted a stock market valuation approach based on event study methodology to investigate the value of IT investment to the firm. Event study method is an efficient tool to capture investors' overall assessment of a firm's value [8], [13], [15], [25]. It measures the stock market's reactions to unexpected events such as announcements of firms' major initiatives to estimate how the event impacts the value of firms. The underlying assumption is that the capital markets are sufficiently capable of evaluating new information about a key event, including IT investment which can potentially impact on expected future profits of the firms, and is reflected in the changes of a firm's stock price [25].

Event study method has been extensively used in the area of finance and economics for a variety of news announcements such as stock splits, layoff announcements, dividend policies, key personnel (CEO) changes [15]. Within the IS literature, the impact of new unexpected announcement has been studied in the areas of general IT investment, e-commerce, outsourcing, security vulnerability, and ERP system [8], [9], [13], [25]. For example, Dos Santos et al., the first paper to use the event study to evaluate IT investment, examined the impact of IT investment announcements on the market value of the firms for a sample of 97 IT investments in the finance and manufacturing industries from 1981 to 1988 [9]. In their study, the overall effect of IT investment announcements on excess market returns was not found to be significant while a significant effect was observed for innovative IT investments. A relationship between e-commerce initiatives announcement and abnormal stock market return was explored in prior research [25]. In their paper, the authors hypothesized that if e-commerce initiatives announcements that might affect a firm's present and future benefit become publicly available, the stock price would change relatively rapidly to reflect the current assessment of the value of the firm. Their hypothesis was supported indicating that capital markets do react positively to firms' announcements of e-commerce initiatives, leading to a significant enhancement of the firm's market value.

\section{Research Hypotheses}

\subsection{RFID Investment Announcements and Market Value}

Consistent with the signaling hypothesis of Fama et al., announcements of RFID investment are a way for organizations to communicate favorable information to investors and stakeholders such as active management involvements on profit generating streams as well as achievement of operational competencies by leveraging new technologies [11]. From an option value perspective, announcements in RFID investment reflect the commitment of companies to build resources and capabilities for new business practices [25] and to assimilate and capitalize on IT innovations [9]. As such, these announcements are expected to favorably place the firms in a position to utilize opportunities, and thus create benefits in the future.

These arguments suggest that firms announcing RFID investments are likely to achieve significant strategic and operational advantages in the future. At a minimum, one would expect RFID to improve the governance of organizational processes due to enhanced inter-organizational integration and information sharing. If relevant, this improvement should eventually be reflected in a firm's value. In other words, investors would interpret investment announcements positively which, in turn, result in a positive abnormal stock market return (that is, risk-adjusted returns in excess of average stock market return) around the date of the announcement [25]. This leads to our first hypothesis that RFID investment announcements are associated with improved future benefit stream and consequently enhanced market valuation.

Hypothesis 1 (H1): RFID investment announcements will produce positive abnormal returns to firms. 


\subsection{Industry Type and Market Value}

However, not all RFID investment has the same potential and option value due to differences in contextual factors such as industry conditions. Based on institutional theory, Sharma et al. suggests that coercive pressure from dominant partners is a significant factor for dependent organizations to adopt new technology [24]. Even though a firm's investment decision on technology is driven by a clear objective with thorough internal and external assessments, companies are, sometimes, being forced into adopting the technology by mandates from their customers or dominant partners. In the case of retail industry, adoption of RFID has been mostly stimulated by global retail giants such as Wal-Mart and Target; not by the inherent benefits of the technology. Many suppliers may not be able to take full advantage of the benefits of integrating RFID technology, although they decide to invest in RFID because it is the best or the only way to satisfy and retain important customers. As a result, the power of RFID technology initiator in this situation can be an important factor determining RFID adoption.

On the other hand, the organizational innovativeness theory supports that a firm's rationale for technology adoption is mainly influenced by its strategic and operational goals to improve the organizational effectiveness and efficiency [24]. In this environment, we may find evidences that voluntary adoption decisions are made to accomplish the company's objectives, and significant efforts are often undertaken to integrate new technologies with existing systems within and across organizations. For instance, in healthcare industry, any single member is not dominant enough to be capable of exercising its power to enforce RFID adoption. This means that one organization's power cannot cause successful adoption of RFID; rather, the decision on technology adoption is made solely based on their needs.

Based on the above arguments, we propose that although RFID investment may benefit firms in all industries, different price reactions to RFID investment announcements across industry sectors are anticipated. Here, we focus on a difference between two broad industry sectors, manufacturing and service sectors, using the Standard Industrial Classification (SIC) system maintained by U.S. Census Bureau. However, given that there is a lack of a priori of the direction of such differences, we assume that there will be a difference between the abnormal returns for different industry sectors, but do not hypothesize any particular strength or direction. Hence, the following hypothesis is presented.

Hypothesis 2 (H2): RFID investment announcements made by firms in different industry sectors will produce different levels of abnormal shareholder returns to the firms.

\section{Research Methodology}

\subsection{Data Collection and Screening}

We employed event-study methodology to analyze the impact of RFID investment announcements on market value of the firms. Information on RFID investment announcements were collected using a full text search of news sources (e.g. PR Newswire and Business Wire) within LexisNexis academic search engine over a six-year period from January 2001 through December 2006. While RFID technology has been around for some time, the environment has significantly changed in late 2003 and early 2004 when Wal-Mart and U.S. Department of Defense established RFID mandates for their major suppliers to adopt the technology [12]. The selection of this sampling timeframe allows us to include the effects of these major mandates of RFID investment.

Firms considered in this study were the constituents of the S\&P 100 as of March 2007 (extracted from http://www.standardandpoors.com). We assumed that since the firms in S\&P 100 are considered the most valuable and are leaders in their industries, any major actions they take may significantly impact future direction of RFID technology. A data set of 100 companies over the six-year period (2001-2006) would allow us to capture any significant market trends in the analysis. The daily returns of the individual S\&P 100 firms were retrieved from the Center for Research on Security Prices (CRSP) database.

Following the search string structure previously used [8], [13], our search keyword contained the verb describing the action of announcements, the noun of the technology, the company name, and the company ticker symbol. In addition, we included the names of major stock exchanges to eliminate firms that are not traded on major security exchanges. The search keyword for announcements contained (launch OR announce OR invest) within the same sentence as the words (RFID OR Radio Frequency Identification) AND (NYSE OR NASDAQ OR AMEX OR OTC) AND (S\&P firm name OR ticker symbol).

Even with the search restriction, the database still yielded thousands of announcement articles initially. We employed a step-by-step process to carefully select announcements to be included in the sample. First, the titles were reviewed to determine whether those articles were related to specific RFID investment announcements. If there were more than one title repeating the same RFID investment announcement, the earliest article was selected. In addition, only articles from daily news sources were retained. After the initial title screening, all of the announcements were read thoroughly to confirm the nature of announcement and only the articles that dealt with RFID investments were included for further screening. This first screening process resulted in an initial sample of 187 announcements. 
The remaining announcements were further examined and screened using multiple criteria. First, we searched other significant events surrounding each event date for each firm, including acquisitions, earning announcements, dividends, stock splits, law suits and other financial events that may generate confounding effects with RFID announcements. Any announcements made on a day with a concurrent confounding event were dropped. Then, we only retained announcements for publicly traded firms in major security exchanges and whose stock market data are available in the CRSP database. Daily returns of each individual firm were then collected from CRSP database. As a result of the above screening processes, the final sample consisted of 128 RFID investment announcements.

Table 2 presents a summary of the sample in our study in terms of industry sectors, industry segments, and announcement years. As shown in Table 2, our sample represents a wide range of industry segments (see panel C) with a majority in the manufacturing sector $(71.9 \%)$ (see panel B). The distribution of RFID announcements across the six-year period indicates that most of RFID investment in the sample occurred in 2004-2006 (110 announcements or $85.9 \%$ ), with the biggest surge in RFID investment in 2004 (50 announcements or $39 \%$ ) (see panel D).

Table 2: Description of sample

\begin{tabular}{|l|l|l|l|}
\hline \multicolumn{2}{|l|}{ Panel A. Breakdown of final sample } & \multicolumn{2}{l|}{ Panel B. Breakdown by SIC code range } \\
\hline $\begin{array}{l}\text { Total initial announcements in Lexis- } \\
\text { Nexis }\end{array}$ & 842 & SIC code <= 5000 (manufacturing sector) & $92(71.9 \%)$ \\
\hline $\begin{array}{l}\text { Less: non-related and duplicate } \\
\text { announcements }\end{array}$ & 232 & SIC code > 5000 (service sector) & $36(28.1 \%)$ \\
\hline Less: non-daily news articles & 187 & \multicolumn{3}{|l|}{} \\
\hline Less: confounding effects & 149 & & \\
\hline Less: CRSP data unavailable & 128 & \multicolumn{2}{|l|}{} \\
\hline Panel C. Breakdown by industry segment & Panel D. Breakdown by year & $2(1.6 \%)$ \\
\hline Industrial & $26(20.3 \%)$ & 2001 & $3(2.3 \%)$ \\
\hline Consumer goods & $20(15.6 \%)$ & 2002 & $13(10.2 \%)$ \\
\hline Information technology & $72(56.3 \%)$ & 2003 & $50(39.1 \%)$ \\
\hline Basic material & $7(5.5 \%)$ & 2004 & $36(28.1 \%)$ \\
\hline Financial & $1(0.8 \%)$ & 2005 & $24(18.8 \%)$ \\
\hline Healthcare & $2(1.6 \%)$ & 2006 & \\
\hline
\end{tabular}

\subsection{Estimation Method}

The impact of RFID investment announcements on stock prices is calculated using event study methodology. Event study method is based on the fundamental assumption that capital markets are sufficiently efficient to evaluate the potential economic impact of new information about key unanticipated business events on future performance of the firms [11].

In order to calculate the market value of an event, the event window - a period of interest for which we observe the event was first determined. We used a three-day event window that include the day before the announcement (day 1 ), the day of the announcement (day 0 ), and the day following the announcement (day +1) for the following reasons. First, by narrowing the event window, we can reduce the noise of possible confounding effects in the data. This is because the longer the event window, the more difficult it is to control for effects of confounding events [15]. Since many organizations in this study are market leaders which, in turn, are likely to have frequent news announcements, the use of a shorter event window can ensure capturing an abnormal return due to the event of interest rather than some other effects. Secondly, a longer event window can decrease the power of the test statistic, $Z_{t}$, which can lead to a false inference of an observation [4]. Hence, we examined the abnormal returns over a three-day event window. While our primary interest would be interpreting the abnormal returns on the event day (day 0), we also included the day following the announcement (day +1 ) as well as the day before (day -1 ) to take into account possible event information leakage prior to the actual announcement.

Once we determined the event window, it is necessary to estimate what the normal return of stock would have been if the announcement had not occurred. The market model assumes a linear relationship between the daily common stock return and the return of market portfolio of stocks [15]. We used the market model to estimate the daily common stock returns to the firms and used S\&P 500 Index for the market returns as follows: 
Where:

$$
\text { (1) } R_{i, t}=\alpha_{i}+\beta_{i} R_{m, t}+\varepsilon_{i, t}
$$

$R_{i, t}=$ the rate of return on the common stock of firm i on day $\mathrm{t}$,

$R_{m, t}=$ the market rate of return on a market portfolio of stocks (S\&P 500 index) on day t,

$\alpha_{i}, \beta_{i}=$ the intercept and slope parameter that measures the sensitivity of $R_{i, t}$ to the market index

$\varepsilon_{i}=$ the error term, with $E\left(\varepsilon_{i, t}\right)=0$

The abnormal return (AR) is calculated for each firm $i$ on day $t$ as the difference between the actual return and the normal return as shown in the following formula:

(2) $A R_{i, t}=R_{i, t}-\left(\alpha_{i}+\beta_{i} R_{m, t}\right)$

The ordinary least square (OLS) parameters $\alpha$ and $\beta$ is first obtained over a specific estimation window, or the period immediately before the event. In this study, we used a 200-day estimation period that begins 201 trading days before the event date, $t=-201$, and ends 2 trading days before the event date, $t=-2$. Basically, the return of the common stock of each firm was regressed against the return of the market index over the 200-day estimation window. The coefficients obtained from the regression were then used to calculate the normal return of the stock in equation 2.

Once abnormal returns to the firms were obtained, standardized abnormal returns (SAR) for firm $\mathrm{i}$ on event day $\mathrm{t}$ were then computed using the following formula:

Where:

$$
\text { (3) } S A R_{i, t}=A R_{i, t} / S D_{i, t}
$$

$S D_{i, t}=\left(S_{i}{ }^{2} \times\left[1+\frac{1}{T}\left(R_{m, t}-R_{m}\right)^{2} / \sum\left(R_{m, t}-R_{m}\right)^{2}\right]\right)^{1 / 2}$

$S_{i}=$ the residual variance from the market model as computed for firm $\mathrm{i}$,

$R_{m}=$ the mean return on the market portfolio during the estimation period,

$T=$ the number of days in the estimation period (200 days)

The above calculated standardized abnormal returns (SAR) were then used to compute the cumulative abnormal return (CAR) for each firm i over the event window $(k)$ as shown below in equation 4.

$$
\text { (4) } C A R_{i}=\left(\frac{1}{k^{1 / 2}}\right) \sum_{t=1} S A R_{i, t}
$$

The values of $C A R_{i}$ are assumed to be independent, normal, and identically distributed [8]. As a result, these values are identically distributed variables when dividing $C A R_{i}$ by its standard deviation, i.e., $[(T-2) /(T-4)]^{1 / 2}$. Then the average standardized cumulative abnormal returns (ASCAR) across $n$ firms over the event window were calculated as follows:

$$
\text { (5) } \operatorname{ASCAR}_{i}=\frac{1}{n} \times \frac{1}{[(T-2) /(T-4)]^{1 / 2}} \times \sum_{i=1} C A R_{i, t}
$$

Finally, to test the hypotheses of whether the average standardized cumulative abnormal return (ASCAR) is significant, we calculated the Z-value as follows:

$$
\text { (6) } Z=A S C A R_{t} \times n^{1 / 2}
$$

The significance of the above calculated test statistics indicates that the average standardized cumulative abnormal return (ASCAR) is significantly different from zero. Based on this test, we can then infer that RFID investment announcements have a significant impact on the market value of the firms. 


\section{Data Analysis and Results}

\subsection{Effects of RFID Investment Announcements on Market Value}

Table 3 presents preliminary results for the test of Hypothesis 1, including average standardized cumulative abnormal returns (ASCAR) and Z-statistics for all 128 RFID investment announcements. The results in Table 3 provide evidence that event-period cumulative abnormal returns (ASCAR $=0.6346 \%, p<.01$ ) are positive and statistically significant for the overall sample of 128 announcements of RFID investment. On average, announcements of RFID initiates generated significant positive price reactions of $0.64 \%$ (at the .01 level) over the three-day event period. Out of 128 announcements, 75 announcements prompted positive returns while 53 announcements receiving negative returns.

It is interesting to note that the abnormal return on day -1 and day 0 are positive and significant and that the abnormal returns for day +1 are positive but not significant. In particular, significant positive abnormal return was found on the day before the announcement (ASCAR $=0.5054 \%, p<.01$ ) as well as the announcement day (ASCAR $=0.3885 \%, p<.05)$. Conversely, no significant abnormal return was observed on the day after the announcement (ASCAR $=0.2052 \%$, n.s.). On average, announcements of RFID initiatives created a significant positive price reaction of $0.51 \%$ on the day before the announcement, which is larger than the price reaction on the announcements day in terms of both significance level and magnitude. This large abnormal return on day -1 may indicate possible information leakage and the anticipation of firm actions of investors and others before the actual news announcement.

Overall, these preliminary findings are consistent with the hypothesis that investors or shareholders recognize the current and future potential of RFID technology and the importance of RFID adoption and investment by early adopters, and react favorably to announcements of these firms' RFID initiatives. Strong support is therefore found for H1.

Table 3: returns to RFID investment announcements $(n=128)$

\begin{tabular}{|l|l|l|l|l|}
\hline & Positive Announcement & CAR & ASCAR (\%) & Z-value \\
\hline Overall Return & $75(58.6 \%)$ & 17.8595 & $\mathbf{0 . 6 3 4 6}$ & $\mathbf{3 . 3 5 8 0}^{\star \star *}$ \\
\hline Day $(\mathrm{t}=-1)$ & & 14.2241 & $\mathbf{0 . 5 0 5 4}$ & $\mathbf{2 . 6 7 4 5}^{\text {**}}$ \\
\hline Day $(\mathrm{t}=0)$ & & 10.9341 & $\mathbf{0 . 3 8 8 5}$ & $\mathbf{2 . 0 5 5 9}^{\star *}$ \\
\hline Day $(\mathrm{t}=+1)$ & & 5.7754 & 0.2052 & 1.0859 \\
\hline
\end{tabular}

${ }^{*} p<0.10,{ }^{* *} p<0.05,{ }^{* * *} p<0.01 ;$ All other unmarked Z-values are not significant

\subsection{Industry Effects of RFID Investment Announcements on Market Value}

Hypothesis 2 posits an industry difference in abnormal returns to firms making RFID investment announcements. To test this hypothesis, the sample was first grouped into two broad industry sectors based on SIC code: manufacturing sector (SIC code>=5000) and service sector (SIC code<5000). Table 4 summarizes the average standardized cumulative abnormal returns (ASCAR) for firms in each industry sector over the 3-day event window and on each individual day.

For firms operating in the manufacturing sector, the overall abnormal returns to RFID investment announcements was found positive and significant (ASCAR=0.7297\%, $p<.01$ ). As expected, the largest return was observed on the announcement day $(A S C A R=0.5418 \%, p<.01)$ while a moderate positive return was found on the day before announcement $(\mathrm{ASCAR}=0.3804 \%, \mathrm{p}<.05)$ and a marginal positive return was found on the day after announcement (ASCAR $=0.3418 \%, p<.10)$. Conversely, for firms in the service sector, the overall abnormal return was positive but not found significant (ASCAR $=0.2858 \%$, n.s.), suggesting that on average announcements of RFID investment does not generate significant increase in the market value of the firms in the service sector. However, interestingly, very significant positive abnormal returns were found for firms in the service sector on day -1 (ASCAR=0.9638\%, $p<.01$ ) whereas the abnormal returns for day 0 and day +1 were found negative and not significant. One possible explanation of this large positive price reaction is that RFID investments made by service firms are primarily for end user applications and it is likely to involve external business partners and technology vendors or consultants. As a result, these external business partners would be aware of the information about RFID investment before the actual press release. Likewise, investors are also likely to be made aware of the RFID investment decision prior to the formal press release and thus perceive and evaluate favorably to RFID investment announcements by service firms on the day before announcement.

These preliminary results provide a strong support of Hypothesis 2 in that RFID investment announcements do produce different stock price reactions for firms in manufacturing versus service industry sectors. First, over the 
three-day event period, announcements of RFID investment on average generated a significant positive price reaction for firms in the manufacturing sector $(0.73 \%$ at the .01 level) but no significant stock price reaction for firms in service sector $(0.28 \%$ and not significant). Second, on each individual day over the three-day event window, the stock price reactions to RFID investment announcements were also different for firms in manufacturing versus service sectors. For manufacturing firms, RFID investment announcements created a much more significant and larger price reaction on the announcement day than on the day before the announcement or the day following the announcement. On the other hand, for service firms, announcements of RFID initiatives created a large price reaction of close to $1 \%$ on the day before announcements but statistically non-significant negative abnormal returns on the announcement day and the day following the announcement. These different patterns in abnormal returns for manufacturing versus service firms suggest that industry differences exist in stock price reactions to RFID investment announcements. For example, investors may more favorably evaluate announcements of new initiatives in RFID technology development of a RFID technology provider firm than announcements of new initiatives in RFID application of a RFID end user firm. To assess such arguments, we conducted two additional analyses to further explore the sources of the above observed industry differences. In the following sections, we present the preliminary results of these analyses.

Table 4: Abnormal returns to RFID investment announcements for manufacturing and service sectors

\begin{tabular}{|l|l|l|l|l|}
\hline & Positive Announcement & CAR & ASCAR (\%) & Z-value \\
\hline Manufacturing sector $(\mathrm{n}=92)$ & $\mathbf{7 5}(58.6 \%)$ & 16.1360 & $\mathbf{0 . 7 2 9 7}$ & $\mathbf{3 . 4 2 2 8}^{\star * *}$ \\
\hline Day $(\mathrm{t}=-1)$ & & 8.4117 & $\mathbf{0 . 3 8 0 4}$ & $\mathbf{1 . 7 8 4 3}^{\star *}$ \\
\hline Day $(\mathrm{t}=0)$ & & 11.9797 & $\mathbf{0 . 5 4 1 8}$ & $\mathbf{2 . 5 4 1 1 ^ { * * * }}$ \\
\hline Day $(\mathrm{t}=-1)$ & & 7.5570 & $\mathbf{0 . 3 4 1 8}$ & $\mathbf{1 . 6 0 3 0}^{*}$ \\
\hline Service sector $(\mathrm{n}=36)$ & $\mathbf{2 2 ( 6 1 . 1 \% )}$ & 1.7235 & 0.2858 & 0.7001 \\
\hline Day $(\mathrm{t}=-1)$ & & 5.8124 & $\mathbf{0 . 9 6 3 8}$ & $\mathbf{2 . 3 6 0 9 ^ { \star * * }}$ \\
\hline Day $(\mathrm{t}=0)$ & & -1.0456 & -0.1734 & -0.4247 \\
\hline Day $(\mathrm{t}=+1)$ & & -1.7816 & -0.2954 & -0.7237 \\
\hline
\end{tabular}

${ }^{*} p<0.10,{ }^{* *} p<0.05,{ }^{* * *} p<0.01$; All other unmarked Z-values are not significant

To further analyze the industry effect, we first partitioned the sample into finer granular industry segments using industry classification system of S\&P 100 index. Six industry segments were identified, but two industry segments financial and health care segments were eliminated from the analysis due to small sample sizes (see Table 2 Panel C). As shown in Table 5, over the 3-day event window, only firms in information technology segment were found to gain a significant positive abnormal return to their RFID investment announcements (ASCAR=1.2721\%, $p<.01$ ). The abnormal returns for firms in industrial and consumer goods industry segments were found positive but not significant while the abnormal returns for firms in basic material industry segment were found negative and not significant. The large price reaction of $1.27 \%$ to announcements of RFID investment for firms in the information technology segment indicates that firms recognize the potential of RFID technology and the importance of RFID adoption/investment initiatives and thus investors favorably react to announcements of RFID investment made by firms in this industry segment. Similarly, announcements of RFID investment also produced a moderate positive abnormal return of $0.46 \%$ for firms in the consumer goods industry segment, although this positive price reaction was not found statistically significant which may be partly due to the relatively small sample size $(n=20)$ of firms in this segment.

Table 5: Abnormal returns to RFID investment announcements for industry segment (S\&P 100 index)

\begin{tabular}{|l|l|l|l|l|}
\hline & Positive Announcement & CAR & ASCAR (\%) & Z-value \\
\hline Industrial $(n=26)$ & $16(61.5 \%)$ & 2.3268 & 0.2894 & 0.8185 \\
\hline Consumer goods $(n=20)$ & $10(50 \%)$ & 3.2705 & 0.4649 & 1.2299 \\
\hline Information technology $(n=72)$ & $43(59.7 \%)$ & 10.2283 & $\mathbf{1 . 2 7 2 1}$ & $\mathbf{3 . 5 9 7 9}$ \\
\hline Basic material $(n=7)$ & $3(42.9 \%)$ & -0.5128 & -0.1701 & -0.2946 \\
\hline
\end{tabular}

${ }^{\star} p<0.10,{ }^{* *} p<0.05,{ }^{* * *} p<0.01$; All other unmarked Z-values are not significant

Furthermore, we also partitioned the sample into an additional grouping by RFID investment type: technology vendor or end user investment. Given the fact that many firms in the information technology industry segment are RFID technology vendors that manufacture RFID tag and reader systems and/or offer RFID solutions to end user firms, the large positive stock price reaction of $1.27 \%$ to these firms indicates that investors may perceive announcements in 
favor of RFID investment for technology infrastructure or solution development by RFID technology vendors. Thus, the 128 announcements in the sample were classified into two types of RFID investments: technology vendor and end user investment. Announcements were coded as RFID end user investment if referring adopting RFID for business applications. Otherwise, the announcements were coded as RFID technology vendor investment when covering RFID technology and standard development. For example, the announcement of Hewlett-Packard Co. and Sun Microsystems Inc. launching test centers and other new offerings to assist companies that need to adopt RFID technology was coded as investment type by technology vendors. On the other hand, the announcement of Procter \& Gamble Co.'s plan to put RFID chips on its products was coded as investment type by end users.

As shown in Table 6, the overall abnormal returns to RFID investment announcements were positive and significant for both technology vendors and end users over the 3-day event window. Interestingly, announcements of RFID investment made by technology vendors generated a much larger and more significant abnormal return (ASCAR $=1.1506 \%, p<.01)$ than that for end users (ASCAR $=0.3480 \%, p<.10)$. This finding indicates technology vendors' announcements of RFID technology development initiatives created much larger stock price reactions with more than three times higher abnormal returns than to RFID investment announcements for specific applications in end user firms.

Table 6: Abnormal returns to RFID investment announcements for investment type

\begin{tabular}{|l|l|l|l|l|}
\hline & Positive Announcement & CAR & ASCAR (\%) & Z-value \\
\hline Technology vendor $(\mathrm{n}=\mathbf{7 7})$ & $46(59.7 \%)$ & 11.5642 & $\mathbf{1 . 1 5 0 6}$ & $\mathbf{3 . 6 3 8 4}^{\star * *}$ \\
\hline End user $(\mathrm{n}=51)$ & $\mathbf{2 9}(56.9 \%)$ & 6.2953 & $\mathbf{0 . 3 4 8 0}$ & $\mathbf{1 . 4 7 6 3}^{\star}$ \\
\hline
\end{tabular}

${ }^{*} p<0.10,{ }^{* *} p<0.05,{ }^{* * *} p<0.01$; All other unmarked Z-values are not significant

Overall, the above preliminary results of the additional analyses of industry effects in abnormal returns to RFID investment announcements provide further insights about our significant findings for Hypothesis 2. Firms in the information technology industry segment seem to garner the biggest abnormal return to their RFID investment announcements. Similarly, announcements of RFID investment in technology or standard development appear to generate much more significant and favorable stock price reactions. These preliminary findings suggest that investors may perceive that the current and future importance and potential of RFID technology are different in different industries and thus react more favorably to announcements made by firms in some industry segments (i.e., information technology segment) or for certain type of RFID investment (i.e., technology vendor investment).

\section{Discussion}

The overall objective of this study is to examine the impacts of RFID investment announcements on the market value of the firms and to explore industry effects of the positive abnormal returns to firms making the announcements. We hypothesized that announcements of RFID investment would result in greater stock market reactions. We also hypothesized that industry differences exist in the abnormal market reactions to RFID announcements, that is, investors assess and react differently to RFID investment announcements in some industries than others. We tested our hypotheses with stock market reactions to RFID investment announcements over a six-year period (2001-2006) during which RFID was an immature emerging technology with great potential to provide a major shift in supply chain management capabilities.

Our initial finding was that overall, RFID investment announcements do produce significant positive increases in market reaction to the firms and, thus, create considerable value for the firms' shareholders. This suggests that investors reward RFID investment announcements: on average, RFID investment firms gained a $0.63 \%$ abnormal market return over the three-day event period. During the studied sampling timeframe of 2001-2006, RFID was considered a technology that can lead to dramatic transformation in supply chain management with improved agility, adaptability, and alignment [7]. At the same time, RFID was still an emerging technology in its mass commercialization infancy that was associated with both technical limitations and uncertainties in technology standards [7]. However, our preliminary finding indicates that investors in general favorably evaluate firms' investment decisions in IT innovations such as RFID. Our finding is consistent with prior research that found a positive, significant market reaction to announcements of innovative IT investments [9]. In addition, the finding of a greater overall excess market return on the day before announcement is not a surprise. Although, the general assumption is that there would be no information leakage prior to the announcement, however, our finding indicates a possible presence of information leakage and an anticipation of firm actions prior to actual press announcements of RFID investment. One possible explanation is that information may have been leaked before the public announcement to large shareholders or management who has better access to inside information as suggested in prior research [25].

Second, a significant industry effect is found on the overall positive abnormal returns to RFID investment announcements. Overall, investors generally react more favorably to announcements made by firms in manufacturing sector than those in service sector. Further analyses provide insights in the possible sources of 
industry effect. Specifically, the finer granular analysis reveals a significant positive abnormal return to announcements for firms in the information technology industry segment. This preliminary finding indicates that investors may collectively recognize positive future benefit streams from investment initiatives in IT innovations such as RFID and thus react favorably to announcements by firms in the information technology industry segment. One plausible explanation is that the ability to quickly sense and seize opportunities from emerging technology innovations in the marketplace with new product/service offerings is regarded as a core competence for firms in the IT industry since IT innovations are the underlying driving force of continuing business growth and competitive advantages to these firms. Furthermore, the analysis of the market reactions to RFID investment for technology vendors versus end users suggests that although both technology vendors and end users garner significant positive abnormal market returns from their RFID investment announcements, technology vendors are able to obtain much larger stock price reactions to their RFID announcements.

The preliminary finding of an industry difference in stock market reactions to RFID announcements, i.e., a greater positive significant abnormal return to announcement for firms in the information technology industry and for technology vendors' RFID initiatives is rather interesting. Considering the fact that RFID is still at its early stage of mass commercialization [7], it is rational that investors would react in favor of investment decisions in RFID by firms in the information technology segment, or technology vendors. The full realization of the value of RFID technology requires widespread adoption of the technology among trading partners and the most frequently cited obstacles of RFID adoption are the cost and complexity of the technology [7]. As such, technology vendors' initiatives such as developing standards, providing new RFID solutions, and launching a RFID research center would be perceived favorably by investors in promoting technology diffusion and a wider scope of adoption of RFID in the future. For example, Hewlett-Packard Co.'s new initiative in launching a test center where companies can test and evaluate equipment in a simulated warehouse environment sends a market signal of its strong commitment to the emerging technology RFID. When such strategic initiative is executed successfully, it can create and enable new business opportunities for the firm. As such, the efficient market would excitedly and favorably respond to the investment announcement in developing RFID technology infrastructure or solutions by technology vendors. On the other hand, when end user companies such as Proctor \& Gamble announced its plan to put RFID chips on its products in broad distribution in 2008 and integrate RFID data with its loyalty card program in 2010, investors would evaluate these announcements of RFID applications with less excitement. One plausible explanation is that while anticipated benefits or total cost savings from RFID investments are expected to be significant, there are still substantial barriers to overcome to realize the potential value from RFID technology. Beyond the technical limitations in RFID technology, some of the biggest obstacles to widespread RFID adoption include relatively high tag price, unreliable hardware, implementation complexity, uncertainty in technology standards, and privacy issues etc. [7]. As such, investors would react more favorably to RFID investment announcements of technology vendors because these firms play a pivotal role in leading the technology diffusion with proactive strategic initiatives in RFID investment.

This paper can also be extended in several directions in future research. First, care must be exercised in generalizing our findings since the sample in this paper was drawn from S\&P 100 firms and those firms were mostly considered large-cap companies. Although our sample size is adequate for the purpose of analysis, a larger data set would have provided a richer understanding and more robust test. Second, while a thorough screening process was taken to control for confounding events, all potential confounding effects cannot be completely eliminated. For example, future studies may control for size of companies since it is possible that the impact of RFID investment announcements may depend on the size of the firm as indicated in previous studies [6], [13]. Lastly, traditional IT event studies including this paper have heavily relied on a parametric analysis of abnormal returns and their significance. As utilized in a few previous studies [6], an incorporation of semi-parametric and non-parametric event study analysis can be useful to verify and/or strengthen the findings in our study. Further, methodologically, other models such as the raw return model, the Fama-French three-factor models, or a custom factor model can be employed to estimate and test the abnormal returns of RFID announcements.

\section{Implications and Conclusion}

This study contributes to the emerging body of research on understanding the adoption and impact of RFID in particular as well as the literature on IT investments and market value in general. The above preliminary findings provide several useful implications for both researchers and practitioners. First, this study provides initial empirical evidence to the benefits of RFID investment and adoption to early adopters in terms of shareholders wealth, or the market value of the firms. The overall positive abnormal returns to RFID investment announcements indicates that investors and market do reward those innovators that proactively embraced RFID at the early stage of mass commercialization of this technology. For an emerging technology like RFID, it has the transformational potential to generate great cost savings and future performance benefits; but at the same time it is also an immature technology that is associated with uncertainty and risk beyond its technical limitations. This finding suggests that firms should continuously monitor new technology innovations, evaluate the benefits and risks of technology innovations, and make judicious decisions in adoption and investment in these emerging technologies. These innovative firms can create shareholder wealth and realize value from their investment initiatives in emerging technology such as RFID. Hence, the positive effect of RFID investment announcements on firm market value found in this paper can be beneficial for companies, in particular, who plan to make future RFID-related decisions and companies who currently defer the adoption of RFID due to its current costs and risks. 
Furthermore, our findings offer a better understanding of the impacts of firms' adoption and investment in emerging technology like RFID by delineating the industry effects of positive returns to RFID investment announcement. The insights from this study can shed light to important decisions such as whether and how a firm should invest in and adopt emerging technology such as RFID. For example, the industry difference in market returns implies that it is necessary to make investment decisions in emerging technologies in sync with industry characteristics. Since investors perceive and evaluate the different importance and potential of an emerging technology like RFID in different industry contexts, firms should assess the costs and benefits of RFID adoption aligning with their operating industry environments to generate the most value from their investment. Likewise, the different market reactions to investment in favoring firms in information technology segment and technology vendors suggest that technology providers may be better off to take the lead to make strategic initiatives in investment in emerging technologies like RFID by campaigning and endorsing the business potential of this technology even when the technology is still at its mass commercialization infancy. This is especially important considering the fact that full realization of the value of RFID relies on widespread adoption of the technology among business partners. However, the biggest hurdles to a large scope adoption are associated with high tag price, implementation complexity, and immature technology. While continuing advances in technology development can overcome some of the barriers over time with cheaper tag price and more reliable hardware, technology vendors' initiatives in RFID can not only contribute to further technology development but also result in simplifying the implementation process. As such, technology vendors play a critical role in shaping the RFID industry and promoting the diffusion of RFID technology by providing confidence in the future potential of the technology with their expertise and commitment. For end user firms of RFID, it is also beneficial to make prudent decisions in RFID initiatives through early experimentation which can help these firms to build up capabilities to effectively utilize and deploy RFID and positively position these firms in seizing future opportunities while RFID is undergoing its technology maturation trajectory.

In summary, this paper sought to examine the impact of RFID investment announcements on the market value of the firms and to explore industry differences of the positive abnormal returns. Drawing upon the efficient market theory, market signaling hypothesis, and prior empirical studies, we employed event study methodology to investigate the research questions. Analyzing a sample of 128 RFID investment announcements over a six-year period from 2001 to 2006, we found that on average RFID investment announcements generated statistically significant, positive increases on the market value of the firms, indicating investors or shareholders perceive RFID initiatives favorably with significant future benefit streams to these firms.

In addition, we also found industry differences in market returns to RFID investment announcements with a greater return realized in the manufacturing sector and specifically in the information technology industry segment. Firms in the information technology segment or RFID technology vendors are able to garner much larger and more significant positive market returns to their RFID investment announcements. The documented positive market returns to RFID investment announcement by early adopters and the significant industry differences in market returns to RFID initiatives provide initial empirical evidence of the benefits of RFID adoption and offer beneficial implications for promoting RFID technology adoption and diffusion in the future. These preliminary findings also provide useful implications for better understanding the impacts of investment in emerging technology such as RFID and for making decisions about whether and how to effectively manage RFID investment and adoption to create value to the firms.

\section{References}

[1] R. Angeles, RFID technologies: Supply-chain applications and implementation issues, Information Systems Management, vol. 22, no. 1, pp. 51-65, 2005.

[2] R. Angeles, An empirical study of the anticipated consumer response to RFID product item tagging, Industrial Management \& Data System, vol. 107, no. 4, pp. 461-483, 2007.

[3] A. Bartels, B.J. Holmes and H. Lo. (2006, November) Global IT spending and investment forecast, 2006 to 2007. Forrester Research. [Online]. Available: http://www.forrester.com/Research/Document/Excerpt/0,7211,40451, 00.html.

[4] S.J. Brown and J.B. Warner, Using daily stock returns: the case of event studies, Journal of Financial Economics, vol. 14, pp. 3-31, 1985.

[5] BusinessWire. (2006, May) Adoption rate of RFID is moving at modest pace, but there is reason to believe growth may be on the way. [Online]. Available: http://findarticles.com/p/articles/mi m0EIN/is 2006 May 22/ai n16374217.

[6] D. Chatterjee, C. Pacini and V. Sambamurthy, The shareholder-wealth and trading-volume effects of information-technology infrastructure investments, Journal of Management Information Systems, vol. 19, no. 2, pp. 7-42, 2002.

[7] J. Curtin, R.J. Kauffman and F.J. Riggins, Making the 'MOST' out of RFID technology: A research agenda for the study of the adoption, usage and impact of RFID, Information Technology and Management, vol. 8, no. 2, pp. 87-110, 2006.

[8] M. Dardan, A. Stylianou and S. Dardan, The valuation of eCommerce announcements during fluctuating financial markets, Journal of Electronic Commerce Research, vol. 6, no. 4, pp. 312-326, 2005.

[9] B.L. Dos_Santos, K. Peffers and D.C. Mauer, The impact of information technology investment announcements on the market value of the firm, Information Systems Research, vol. 4, no. 1, pp. 1-23, 1993. 
[10] B. Eckfeldt, What does RFID do for the consumer?, Communications of the ACM, vol. 48, no. 9, pp. 77-79, 2005.

[11] E. Fama, L. Fisher, M. Jensen and R. Roll, The adjustment of stock prices to new information, International Economic Review, vol. 10, no. 1, pp. 1-21, 1969.

[12] L.A. Fish and W.C. Forrest. (2006, September) The 7 success factors of RFID. Supply Chain Management Review. [Online]. Available: http://www.scmr.com/article/CA6376444.html.

[13] K.S. Im, K.E. Dow and V. Grover, A reexamination of IT investment and the market value of the firm: an event study methodology, Information Systems Research, vol. 12, no. 1, pp. 103-117, 2001.

[14] V. Matta and C. Moberg, The development of a research agenda for RFID adoption and effectiveness in supply chains, Issues in Information Systems, vol. 7, no. 2, pp. 246-251, 2006.

[15] A. McWilliams and D. Siegel, Event studies in management research: Theoretical and empirical issues, The Academy of Management Journal, vol. 40, no. 3, pp. 626-657, 1997.

[16] N. Melville, K. Kraemer and V. Gurbaxani, Review: Information technology and organizational performance: An integrative model of IT business value, MIS Quarterly, vol. 28, no. 2, pp. 283-322, 2004.

[17] K. Michael and L. McCathie, The pros and cons of RFID in supply chain management, in Proceedings of the International Conference on Mobile Business, 2005, pp. 623-629.

[18] C.R. Moberg, T.W. Speh and T.L. Freese, SCM: Making a vision a reality, Supply Chain Management Review, vol. 7, no. 5, pp. 34-39, 2003.

[19] F. Niederman, R.G. Mathieu, R. Morley and I.W. Kwon, Examining RFID applications in supply chain management, Communications of the ACM, vol. 50, no. 7, pp. 92-101, 2007.

[20] K. Pramatari, Collaborative supply chain practices and evolving technological approaches, Supply Chain Management: An International Journal, vol. 12, no. 3, pp. 210-220, 2007.

[21] E. Prater, G.V. Frazier and P.M. Reyes, Future impacts of RFID on e-supply chains in grocery retailing, Supply Chain Management: An International Journal, vol. 10, no. 2, pp. 134-142, 2005.

[22] P.M. Reyes and P. Jaska, Is RFID right for your organization or application?, Management Research News, vol. 30, no. 8, pp. 570-580, 2007.

[23] R. Sabherwal and S. Sabherwal, Knowledge management using information technology: Determinants of shortterm impact on firm value, Decision Sciences, vol. 36, no. 4, pp. 531-567, 2005.

[24] A. Sharma, A. Citurs and B. Konsynski, Strategic and institutional perspectives in the adoption and early integration of radio frequency identification (RFID), in Proceedings of the 40th Annual Hawaii International Conference on System Sciences, 2007, pp. 224c.

[25] M. Subramani and E. Walden, The impact of e-commerce announcement on the market value of firms, Information Systems Research, vol. 12, no. 2, pp. 135-154, 2001.

[26] G. Yang and S.L. Jarvenpaa, Trust and radio frequency identification (RFID) adoption within an alliance, in Proceedings of the 38th Hawaii International Conference on System Sciences, 2005, pp. 208a. 


\section{Appendix}

Representative RFID Investment Announcements in the Sample

\begin{tabular}{|c|c|c|}
\hline $\begin{array}{c}\text { Announcement Date } \\
\text { / Source }\end{array}$ & Announcements (Abbreviated) & Industry \\
\hline $\begin{array}{l}\text { September 27, } 2004 \text { / } \\
\text { eWeek }\end{array}$ & $\begin{array}{l}\text { UPS is working on better ways to keep track of packages. This } \\
\text { involves a comprehensive trial of RFID (radio-frequency } \\
\text { identification) tagging, which eliminates the line of sight that bar- } \\
\text { code scanning requires. UPS is heavily involved in developing } \\
\text { standards for RFID; working with organizations ranging from } \\
\text { EPCglobal Inc. to the Federal Aviation Administration. }\end{array}$ & $\begin{array}{l}\text { Manufacture } \\
\text { (Industrial) }\end{array}$ \\
\hline $\begin{array}{l}\text { September 12, } 2006 \text { / } \\
\text { PR Newswire US }\end{array}$ & $\begin{array}{l}\text { Wal-Mart Stores, Inc. (NYSE:WMT) will bring another } 500 \text { stores } \\
\text { and clubs online with its RFID (radio frequency identification) } \\
\text { initiative by the end of this fiscal year, bringing the total number } \\
\text { of its retail locations using the technology to more than } 1,000 \text {. }\end{array}$ & $\begin{array}{l}\text { Service } \\
\text { (Consumer } \\
\text { Staples) }\end{array}$ \\
\hline $\begin{array}{l}\text { May 10, } 2004 \text { / } \\
\text { Computerworld }\end{array}$ & $\begin{array}{l}\text { HP today announces the launch of its RFID Center of Excellence } \\
\text { in Palo Alto, Calif., where customers can learn more about the } \\
\text { vendor's RFID vision, build RFID road maps, and conduct proofs } \\
\text { of concept. HP services unit also introduced a trio of new } \\
\text { offerings: an RFID Discovery Service to help companies that are } \\
\text { developing their own RFID strategies }\end{array}$ & $\begin{array}{l}\text { Manufacture } \\
\text { (IT) }\end{array}$ \\
\hline $\begin{array}{l}\text { November 15, } 2004 \text { / } \\
\text { PR Newswire US }\end{array}$ & $\begin{array}{l}\text { In a continuing effort to combat drug counterfeiting and protect } \\
\text { patients, Pfizer has announced a new initiative to use radio } \\
\text { frequency identification (RFID) tags that will enable wholesalers } \\
\text { and pharmacies to authenticate all Viagra sold in the United } \\
\text { States. Pfizer will begin planning for the project immediately and } \\
\text { has set a goal to start shipping Viagra with RFID technology by } \\
\text { the end of next year. }\end{array}$ & $\begin{array}{l}\text { Manufacture } \\
\text { (Health Care) }\end{array}$ \\
\hline $\begin{array}{l}\text { April 5, } 2004 \text { / } \\
\text { InfoWorld Daily News }\end{array}$ & $\begin{array}{l}\text { Emphasizing ambitions in RFID (radio frequency identification), } \\
\text { Microsoft on Monday will announce formation of the Microsoft } \\
\text { RFID Council, a multi-vendor group that will study requirements } \\
\text { for Microsoft software to participate in RFID data processing } \\
\text { systems. The company also will announce that it joined } \\
\text { EPCglobal in March. }\end{array}$ & Service (IT) \\
\hline $\begin{array}{l}\text { January 5, } 2001 \text { / } \\
\text { Canada Newswire }\end{array}$ & $\begin{array}{l}\text { SAMSys Technologies Inc., a provider of Radio Frequency } \\
\text { Identification (RFID) reader hardware, has been selected to } \\
\text { participate in International Paper Co.'s smart packaging initiative } \\
\text { as its primary supplier of passive RFID reader hardware. } \\
\text { International Paper smart packaging initiative is projected to play } \\
\text { a major role in the reinvention of the global supply chain. Its } \\
\text { mandate is to seek opportunities to deploy smart packaging } \\
\text { RFID technologies to enhance data flow within operations of } \\
\text { companies. }\end{array}$ & $\begin{array}{l}\text { Manufacture } \\
\text { (Material) }\end{array}$ \\
\hline $\begin{array}{l}\text { February 24, } 2004 \text { / } \\
\text { Star Tribune }\end{array}$ & $\begin{array}{l}\text { Target Corp. has told its largest suppliers that they must place } \\
\text { radio frequency identification (RFID) tags on all pallets and } \\
\text { cases of goods shipped to certain of its regional distribution } \\
\text { centers by late spring } 2005 \text {. By spring } 2007 \text {, all of Target's } \\
\text { suppliers will have to place RFID tags on pallets and cases as a } \\
\text { supplement to bar codes - but not a replacement. }\end{array}$ & $\begin{array}{l}\text { Service } \\
\text { (Consumer } \\
\text { Discretionary) }\end{array}$ \\
\hline $\begin{array}{l}\text { April 12, } 2005 \text { / } \\
\text { PR Newswire US }\end{array}$ & $\begin{array}{l}\text { Enabling its partners to deliver complete RFID solutions, Oracle } \\
\text { today announced the launch of its Sensor-Based Services } \\
\text { Initiative offered through the Oracle(R) Partner Network. Oracle } \\
\text { Sensor-Based Services' partners are integral in helping promote } \\
\text { customer adoption of RFID and sensor technology. }\end{array}$ & Service (IT) \\
\hline
\end{tabular}

